\title{
EFEKTIVITAS PENGGUNAAN MEDIA VISUAL TERHADAP MOTIVASI BELAJAR DAN PRESTASI BELAJAR SISWA KELAS III SD GUGUS 01 IMOGIRI, BANTUL
}

\author{
Eti Surwantini \\ SD Siluk Imogiri Bantul \\ Email: umieihda@gmail.com
}

\begin{abstract}
Abstrak
Penelitian ini bertujuan mengungkap: 1) perbedaan prestasi belajar siswa yang diajar dengan menggunakan media visual dan tanpa media visual; 2) efektivitas penggunaan media visual terhadap prestasi belajar; 3) perbedaan motivasi belajar siswa yang diajar dengan menggunakan media visual dan tanpa media visual dan 4) efektivitas penggunaan media visual terhadap motivasi belajar pada pembelajaran tematik dengan tema kegiatan sehari-hari. Penelitian menggunakan metode eksperimen semu. Penelitian dilakukan pada siswa kelas III SD di Gugus 01 Kecamatan Imogiri. Desain penelitian yang digunakan adalah nonequivalent pretest posttest control group design. Pengumpulan data menggunakan tes prestasi belajar dan skala motivasi belajar. Teknik analisis data dengan anova dan one sample $t$ test. Hasil penelitian menunjukkan terdapat perbedaan yang signifikan pada hasil akhir prestasi belajar siswa kelas eksperimen dan kelas kontrol dengan $p<0.05$ dan media visual terbukti efektif terhadap prestasi belajar. Tidak ada perbedaan yang signifikan pada skor akhir motivasi belajar siswa kelas eksperimen dan kelas kontrol karena $p>0.05$ namun media visual lebih efektif daripada media konvensional terhadap motivasi belajar siswa.
\end{abstract}

Kata kunci: media visual, motivasi belajar, dan prestasi belajar

\section{THE EFFECTIVENESS OF USING VISUAL MEDIA ON THE LEARNING MOTIVATION AND ACHIEVEMENT OF GRADE III STUDENTS OF CLUSTER I ELEMENTARY SCHOOL IN DISTRICT OF IMOGIRI, BANTUL}

\begin{abstract}
This research aims to reveal: 1) difference in learning achievement of the students taught by using visual media and that of those taught with no visual media; 2) the effectiveness of the use of visual media on the learning achievement; 3) difference in learning motivation of the students taught by using visual media and that of those taught with no visual media and 4) the effectiveness of the use of visual media on the learning motivation in the thematic learning theme of daily activities. This research used a quasi-experiment method. This study was conducted at the thrid grade students of cluster 1 elementary school in district of Imogiri. This study used the nonequivalent pretest posttest control group design. The data collection used student achievement test and learning motivation scale. The data analysis techniques used were ANOVA and one-sample $t$ test. The results show a significant difference in the final results of learning achievement between the experimental class and control class with $P<0.05$ and visual media prove to be effective on learning achievement. There is no significant difference in the final score of learning motivation between the experimental class and control class because of $p>0.05$ but visual media more effective than convensional media on student's motivation.
\end{abstract}

Keywords: visual media, learning motivation, and learning achievement 


\section{PENDAHULUAN}

Motivasi belajar dan prestasi belajar merupakan dua hal yang tidak dapat dipisahkan. Keduanya ibarat dua mata pisau yang selalu berjalan beriringan. Motivasi belajar dan prestasi belajar dari siswa dapat ditumbuhkan dengan aktivitas belajar yang menarik yaitu melibatkan siswa aktif menemukan pengetahuannya sendiri didukung dengan penggunaan media pembelajaran yang tepat dan menarik bagi siswa.

Aktivitas belajar siswa selama di sekolah khususnya di dalam kelas menjadi tanggung jawab guru. Guru harus menyediakan pembelajaran yang menarik untuk siswa. Proses pembelajaran harus dirancang untuk mengakomodasi kebutuhan siswa. Hal ini dapat diciptakan guru jika proses pembelajaran yang akan berlangsung direncanakan dengan baik terutama dalam hal penggunan media pembelajaran.

Proses pembelajaran yang dilaksanakan untuk siswa kelas rendah seperti kelas III SD adalah dengan pembelajaran tematik. Pembelajaran tematik adalah pembelajaran terpadu yang menggunakan tema. Pembelajaran dilakukan dengan memberi pengalaman yang bermakna kepada siswa. Pelajaran-pelajaran diintegrasikan melalui tema-tema yang sudah ditetapkan.

Pada hakikatnya pembelajaran tematik di SD memiliki beberapa tujuan. Tujuan tersebut menurut Majid (2014:87) diantaranya adalah untuk memusatkan perhatian peserta didik dengan mudah pada suatu tema materi yang jelas, mengembangkan berbagai kompetensi dasar antar mata pelajaran dalam tema yang sama atau mengaitkan tema pelajaran satu dengan yang lain, pemahaman terhadap materi pelajaran lebih mendalam dan berkesan, dan memudahkan guru dalam mempersiapkan dan menyajikan bahan ajar yang efektif.

Dari tujuan yang disebutkan di atas diharapkan siswa akan memiliki rasa senang dan aktif saat belajar sehingga memiliki motivasi belajar dan prestasi belajar yang maksimal. Guru sebagai fasilitator pada saat pembelajaran harus berusaha semaksimal mungkin agar bisa memfasilitasi penyampaian materi yang sesuai dengan taraf perkembangan siswa sehingga tujuan yang diharapkan benarbenar bisa terwujud. Inilah tantangan bagi guru agar pembelajaran menjadi menarik dan menyenangkan bagi siswa sehingga materi-materi yang ada dalam ruang lingkup pembelajaran dapat diserap dengan baik.

Implikasi dalam pembelajaran tematik pada dasarnya tidak hanya dari faktor guru dan siswa. Faktor sarana dan prasarana seperti mengoptimalkan penggunaan variasi media juga sangat penting. Variasi media dalam pembelajaran akan membuat siswa tertarik dan membantunya untuk lebih memahami materi yang diajarkan. Dengan media pembelajaran yang menarik dan menyenangkan diharapkan siswa akan dapat memiliki motivasi dan prestasi belajar yang tinggi. Hal tersebut sesuai dengan Ngure et al (2014:6):

Many teachers who use instructional media find that it can help them improve student learning and motivation, address students with different learning abilities, expose students to a wider world of information and experts and implement new teaching techniques in all levels of learning including teacher training colleges.

Pendapat di atas menegaskan bahwa banyak manfaat yang diperoleh guru yang menggunakan media pembelajaran di kelas. Manfaat tersebut diantaranya meningkatkan hasil dari belajar dan motivasi siswa.

Motivasi belajar sangat diperlukan oleh siswa. Siswa yang memiliki motivasi belajar akan bersemangat dalam aktivitas belajarnya. Motivasi belajar pada seseorang diibaratkan seperti bahan bakar pada mesin ataupun kendaraan. Jika tidak ada maka mesin ataupun kendaraan akan

Efektivitas Penggunaan Media Visual terhadap Motivasi Belajar dan Prestasi Belajar Siswa ... 
mogok atau tidak bisa berjalan sama sekali. Demikian halnya pada diri siswa jika tidak ada motivasi belajar pada dirinya maka aktivitas belajar tidak akan maksimal karena merasa bosan ataupun malas.

Aktivitas belajar yang kurang maksimal akan menghambat pula pencapaian prestasi belajar pada diri siswa. Sebagai contoh adalah aktivitas belajar yang monoton tanpa adanya media pembelajaran yang mendukung akan mengakibatkan siswa jenuh dan malas. Tentu saja siswa yang malas tidak akan maksimal dalam menyerap ilmu pengetahuan ataupun pengalaman belajar yang diberikan oleh guru. Dalam hal ini penting bagi seorang guru untuk memahami kondisi siswa saat pembelajaran berlangsung sehingga siswa dapat mencapai tujuan dan prestasi belajar yang maksimal.

Prestasi dan motivasi belajar siswa merupakan dua hal yang tidak bisa lepas dari perhatian guru. Mengingat dua hal tersebut merupakan salah satu faktor yang penting dalam keberhasilan siswa. Keberhasilan siswa tentu saja tercemin dari berhasil tidaknya siswa mencapai tujuan belajar yang telah ditetapkan. Motivasi belajar dan keberhasilan siswa di kelas dalam mencapai tujuan belajar yang ditetapkan menjadi tanggung jawab guru. Motivasi belajar dapat ditumbuhkan oleh guru dengan menciptakan pembelajaran yang kondusif dan menyenangkan bagi siswa.

Pembelajaran yang kondusif dan menyenangkan dapat diciptakan dengan berbagai hal misalnya menggunakan pendekatan yang sesuai, metode yang mengaktifkan siswa, media yang menarik bagi siswa, sumber belajar yang bervariasi dan lain sebagainya. Dalam proses perencanaannya membutuhkan ide kreatif dari masing-masing guru untuk menghasilkan pembelajaran aktif dan menyenangkan bagi siswa. Yaitu pembelajaran yang dapat mengakomodasi kebutuhan dan karakteristik siswa, serta mampu memberi pengalaman bermakna bagi siswa dengan media yang mendukung.

Media merupakan satu hal yang penting dalam proses pembelajaran. Media tidak hanya dapat menarik perhatian siswa tapi juga dapat membuat siswa lebih paham tentang materi yang disampaikan. Selain itu media di kelas-kelas rendah yaitu kelas 1, 2, dan 3 dapat dijadikan sarana untuk belajar sambil bermain. Pada hakikatnya siswa di kelas rendah senang bermain sambil belajar. Mereka dapat belajar dengan mengeksplorasi media pembelajaran yang ada. Sudah seharusnya bagi guru untuk menyediakan media pembelajaran yang menarik sehingga siswa akan bersemangat dan memperoleh hasil yang maksimal.

Namun, sepertinya kondisi ideal yang diharapkan belum maksimal terlaksana di beberapa tempat. Menurut data hasil penelitian Benson \& Odera (2013:23) menyebutkan bahwa dalam pembelajaran di Kenya banyak guru yang menggunakan media seperti papan tulis dan buku teks pelajaran dan belum menggunakan variasi media dalam pembelajaran khususnya pembelajaran Bahasa Kishwahili. Sukini (2012:68) menuliskan bahwa implementasi pembelajaran tematik dalam hal penggunaan media khususnya dalam hal penggunaan media belum begitu memadai. Artinya penggunaan media dalam pembelajaran tematik belum optimal.

Hal di atas juga terjadi di SD se-gugus 01 Kecamatan Imogiri. Pada proses pembelajaran khususnya pada pembelajaran tematik di kelas III SD belum melibatkan keaktifan siswa, masih sedikit guru yang menggunakan media dalam proses pembelajaran di kelas dan guru belum begitu memperhatikan pentingnya motivasi belajar bagi para siswanya. Yang terpenting siswa duduk diam mendengarkan penjelasan dari guru.

Pada pembelajaran tematik di kelas III SD belum digunakan media yang menarik efektif dan efisien bagi siswa dalam proses pembelajaran tematik untuk menstimulus 
motivasi belajar dan prestasi belajar siswa. Guru belum begitu terbiasa menggunakan media yang dapat digunakan untuk pembelajaran tematik artinya media yang tidak hanya untuk satu mata pelajaran saja namun sesuai dengan tujuan pembelajaran dalam tema yang diajarkan. Hal tersebut tentunya akan menimbulkan kejenuhan serta kebosanan dalam diri siswa karena pembelajaran lebih banyak didominasi guru tanpa melibatkan siswa secara aktif. Akibatnya siswa akan menjadi malas, bosan, mengantuk dan ramai sendiri di kelas. Pembelajaran tematik biasanya diajarkan tanpa menggunakan media yang sesuai. Artinya media yang digunakan hanya untuk satu mata pelajaran saja. Media hanya digunakan jika sudah tersedia di buku ataupun di sekolah dan penggunaannya tidak maksimal artinya kadang-kadang digunakan kadang tidak. Itupun hanya digunakan pelajaran tertentu misalnya materi IPA, padahal pembelajaran yang dilaksanakan adalah pembelajaran tematik. Tentu saja materi dalam mata pelajaran lain dalam pembelajaran tematik juga sangat memerlukan media untuk membantu siswa dalam memahami materi.

Melihat fenomena permasalahan di atas, kiranya perlu dilakukan langkah tepat dalam pembelajaran tematik khususnya dalam hal penggunaan media pembelajaran yang sesuai dalam pembelajaran tematik yang efektif untuk meningkatkan motivasi belajar dan prestasi siswa. Pembelajaran hendaknya dilaksanakan dengan efektif dengan media yang menarik se-hingga dapat berpengaruh terhadap proses dan hasil belajar siswa. Menghadirkan media yang cocok atau sesuai dalam pembelajaran khususnya pembelajaran tematik sangat diperlukan untuk membantu siswa dalam belajar.

Media visual digunakan sebagai media dalam pembelajaran tematik di kelas III SD karena mempunyai nilai kepraktisan, mudah dibuat dan dapat menggunakan bahan-bahan yang dekat dan banyak terdapat di sekitar siswa. Siswa dapat bermain sambil belajar dengan menggunakan media visual. Media visual yang digunakan dalam penelitian ini adalah puzzle, ular tangga dan kartu cari pasanganku yang bisa digunakan siswa kelas III untuk bermain sambil belajar.

Alasan pemilihan media visual dalam pembelajaran tematik dalam penelitian ini karena selain sederhana dan mudah dibuat, media visual juga sangat menarik jika dikemas dengan baik dalam penyajiannya. Pembelajaran dengan media tersebut memudahkan siswa untuk memahami konsep-konsep materi ada dalam tema karena distimulus oleh visualisasi dari media visual tersebut. Media visual yang penyajiannya menarik diharapkan mampu memotivasi siswa untuk belajar, memudahkan siswa memahami materi yang disampaikan, sehingga siswa dapat memperoleh hasil yang maksimal.

Dari beberapa fakta yang ditemukan seperti pembelajaran tematik di kelas III SD Gugus 01 Imogiri belum menggunakan media yang efektif dan efisien, media yang digunakan guru terbatas pada apa yang ada pada buku pelajaran atau menggunakan media konvensional yaitu papan tulis dan belum digunakannya media visual seperti puzzle, ular tangga dan kartu cari pasangan untuk meningkatkan prestasi belajar dan motivasi belajar dalam pembelajaran tematik kelas III SD. Maka penelitian ini dibatasi pada efektivitas penggunaan media visual dibandingkan media konvensional yaitu papan tulis dan kapur berwarna terhadap motivasi belajar dan prestasi belajar siswa pada pembelajaran tematik tema kegiatan sehari-hari pada siswa kelas III SD di Gugus 01 Kecamatan Imogiri.

Penelitian ini secara khusus bertujuan untuk mengungkap: (1) perbedaan prestasi belajar siswa yang diajar dengan menggunakan media visual dan tanpa media visual, (2) efektivitas penggunaan media visual terhadap prestasi belajar, 
(3) perbedaan motivasi belajar siswa yang diajar dengan menggunakan media visual dan tanpa media visual dan (4) efektivitas penggunaan media visual terhadap motivasi belajar pada pembelajaran tematik dengan tema kegiatan sehari-hari.

\section{METODE}

\section{Jenis Penelitian}

Penelitian ini menggunakan pendekatan kuantitatif. Penelitian merupakan penelitian eksperimen semu. Desain yang digunakan adalah Nonequivalent Pretest Posttest Control Group Design.

\section{Waktu dan Tempat Penelitian}

Penelitian dilakukan pada bulan April - Mei 2015. Penelitian dilakukan di Gugus 01 Kecamatan Imogiri yaitu di SD Lanteng Baru dan SD Siluk.

\section{Populasi dan Sampel Penelitian}

Populasi pada penelitian ini adalah seluruh siswa kelas III SD yang berada pada gugus 01 Kecamatan Imogiri. Sampel dipilih menggunakan teknik cluster random sampling, yaitu pemilihan sampel berdasarkan kelas yang sudah ada dalam populasi. Tiga kelas sampel dipilih secara acak. Diperoleh kelas IIIA SD Lanteng baru sebagai kelas eksperimen 1 (KE1), kelas IIIB SD Lanteng Baru sebagai kelas eksperimen 2 (KE2) dan kelas III SD Siluk sebagai kelas kontrol (KK).

\section{Prosedur}

Prosedur penelitian disusun secara runtut untuk memudahkan dalam penelitian ini. Prosedur penelitian yang digunakan adalah sebagai berikut: (1) Menentukan populasi dan sampel penelitian, (2) Membuat instrumen pretest dan skala motivasi belajar, (3) Mengujicobakan instrument, (4) Menganalisis data hasil ujicoba instrument, (5) Melakukan pretest dan skala motivasi belajar, (6) Menganalisis hasil pretest dan skala motivasi belajar, (7) Melaksanakan penelitian , (8) Melakukan posttest dan skala akhir motivasi belajar dan

(9) Menganalisis data hasil penelitian.

Gambaran rancangan penelitian (Shaughnessy, Zechmeister \& Zechmeister, 2012:304) dapat dilihat pada Tabel 1 sebagai berikut.

Tabel 1. Rancangan Penelitian

\begin{tabular}{lccc}
\hline Kelompok & Pretest & Perlakuan & Posttest \\
\hline KE1 & O1 & $\mathrm{X} 1$ & $\mathrm{O} 2$ \\
KE2 & $\mathrm{O} 1$ & $\mathrm{X} 1$ & $\mathrm{O} 2$ \\
KK & $\mathrm{O} 1$ & $\mathrm{X} 2$ & $\mathrm{O} 2$ \\
\hline
\end{tabular}

Keterangan:

KE1 : Kelas Eksperimen 1

KE2: Kelas Eksperimen 2

KK : Kelas Kontrol

O1 : Pengukuran kemampuan awal dan motivasi awal

O2 : Pengukuran kemampuan akhir dan motivasi akhir

$X_{1}$ : Pembelajaran dengan pemberian perlakuan dengan media visual berupa puzzle, ular tangga dan kartu cari pasangan.

$\mathrm{X}_{2}$ : Pembelajaran dengan media konvensional (papan tulis dan kapur berwarna)

Data, Instrumen, dan Teknik Pengumpulan Data

Data berupa skor prestasi belajar dan motivasi belajar. Skor hasil prestasi belajar dikumpulkan menggunakan tes hasil belajar. Skor hasil motivasi belajar dikumpulkan menggunakan skala motivasi belajar.

\section{Teknik Analisis Data}

Data dianalisis dengan menggunakan teknik analisis data deskriptif dan inferensial. Analisis deskriptif digunakan untuk mendeskripsikan skor prestasi belajar dan motivasi belajar siswa pada ketiga kelas. Deskripsi data tersebut berupa nilai maksimum, nilai minimum, nilai ratarata, median, modus, standar deviasi dan varians.

Analisis inferensial digunakan untuk pengujian hipotesis. Hipotesis pertama dan ketiga menggunakan one way anova sedang untuk hipotesis kedua dan ke- 
empat digunakan uji-t yaitu one sample $t$ test, menggunakan program SPSS 17.0. Sebelum dilakukan pengujian tersebut, terlebih dahulu dilakukan uji prasyarat. Uji prasyarat yang dimaksud adalah uji normalitas dan uji homogenitas.

Adapun hipotesis dalam penelitian ini adalah: (1) Ada perbedaan signifikan pada prestasi belajar antara pembelajaran dengan media visual dengan pembelajaran konvesional tanpa media visual pada pembelajaran tematik tema kegiatan sehari-hari siswa kelas III SD Gugus 01 Kecamatan Imogiri, (2) Penggunaan media visual lebih efektif dibandingkan penggunaan media konvensional terhadap prestasi belajar pada pembelajaran tematik tema kegiatan sehari-hari pada siswa kelas III SD Gugus 01 Kecamatan Imogiri, (3) Ada perbedaan signifikan pada motivasi belajar antara pembelajaran dengan media visual dengan pembelajaran konvesional tanpa media visual pada pembelajaran tematik tema kegiatan sehari-hari siswa kelas III SD Gugus 01 Kecamatan Imogiri, dan (4) Penggunaan media visual lebih efektif dibandingkan penggunaan media konvensional terhadap motivasi belajar pada pembelajaran tematik tema kegiatan sehari-hari pada siswa kelas III SD Gugus 01 Kecamatan Imogiri.

\section{HASIL DAN PEMBAHASAN}

Deskripsi Hasil Penelitian

Data yang diperoleh dari penelitian ini adalah data prestasi belajar dan motivasi belajar siswa kelas III SD. Data dalam penelitian ini adalah data yang dihasilkan dari data prestasi belajar siswa yaitu diperoleh dari hasil pretest dan posttest terhadap kelas kontrol dan kelas eksperimen serta data skor skala motivasi belajar siswa. Data pretest dan posttest masing-masing disajikan ke dalam tabel 2 berikut.

\section{Data Pretest dan Posttest Prestasi Belajar \\ Data pretest dan posttest masing-masing} kelas disajikan ke dalam tabel 2 berikut.

Tabel 2 merupakan rangkuman nilai pretest dan posttest pada kelas kontrol dan kelas eksperimen. Nilai rata-rata pretest pada kelas kontrol adalah 67.75 sedangkan nilai pretest pada kelas eksperimen 1 dan 2 secara berturut-turut adalah 67.75 dan 67.60. Rata-rata nilai pretest pada ketiga kelas menunjukkan kesamaan nilai antara ketiga kelas. Nilai rata-rata posttest pada kelas kontrol 68.12 sedangkan pada kelas eksperimen 1 dan 2 masing-masing adalah 78.99 dan 78.66. Dari nilai posttest terlihat bahwa kelas eksperimen 1 dan 2 memiliki nilai yang lebih tinggi dari kelas kontrol.

Tabel 2. Data Pretest Kelas Eksperimen 1, Kelas Eksperimen 2 dan Kelas Kontrol

\begin{tabular}{lccccc}
\hline Sumber & $\mathbf{N}$ & $\begin{array}{c}\text { Nilai } \\
\text { Minimum }\end{array}$ & $\begin{array}{c}\text { Nilai } \\
\text { Maksimum }\end{array}$ & Mean & $\begin{array}{c}\text { Standar } \\
\text { Deviasi }\end{array}$ \\
\hline $\begin{array}{l}\text { Kontrol } \\
\text { Pretest }\end{array}$ & 12 & 43.48 & 86.96 & 67.75 & 12.77 \\
$\begin{array}{l}\text { Posttest } \\
\text { Eksperimen 1 }\end{array}$ & 12 & 43.48 & 86.96 & 68.12 & 13.02 \\
$\begin{array}{l}\text { Pretest } \\
\text { Posttest }\end{array}$ & 18 & 43.48 & 82.61 & 67.15 & 12.761 \\
Eksperimen 2 & 18 & 56.52 & 91.30 & 78.99 & 8.2021 \\
$\begin{array}{l}\text { Pretest } \\
\text { Posttest }\end{array}$ & 22 & 43.50 & 82.61 & 67.60 & 11.50 \\
\hline & 22 & 56.52 & 91.30 & 78.66 & 9.38 \\
\hline
\end{tabular}

Efektivitas Penggunaan Media Visual terhadap Motivasi Belajar dan Prestasi Belajar Siswa ... 
Tabel 3. Data Skor Motivasi Belajar Kelas Eksperimen 1, Kelas Eksperimen 2 dan Kelas Kontrol

\begin{tabular}{lccccc}
\hline \multicolumn{1}{c}{ Sumber } & $\mathbf{N}$ & $\begin{array}{c}\text { Skor } \\
\text { Minimum }\end{array}$ & $\begin{array}{c}\text { Skor } \\
\text { Maksimum }\end{array}$ & Mean & $\begin{array}{c}\text { Standar } \\
\text { Deviasi }\end{array}$ \\
\hline $\begin{array}{l}\text { Kontrol } \\
\text { Awal }\end{array}$ & 12 & 58 & 97 & 80.33 & 10.731 \\
$\begin{array}{l}\text { Akhir } \\
\text { Eksperimen 1 }\end{array}$ & 12 & 58 & 97 & 81.41 & 10.983 \\
Awal & 18 & 66 & 97 & 81.67 & 9.573 \\
Akhir & 18 & 73 & 104 & 88.72 & 9.523 \\
Eksperimen 2 & & & & & \\
Awal & 22 & 63 & 94 & 78.41 & 8.192 \\
Akhir & 22 & 72 & 102 & 87.77 & 8.507 \\
\hline
\end{tabular}

Data Skor Awal dan Akhir Motivasi Belajar

Data skor motivasi belajar disajikan dalam tabel 3.

Dari tabel 3 skor awal motivasi belajar siswa pada ketiga kelas dapat dikatakan hampir sama yaitu secara berturut-turut 80.33 pada kelas kontrol, 81.67 pada kelas eksperimen 1 dan 78.41 pada kelas eksperimen 2. Skor awal ketiga kelas masuk dalam kategori motivasi belajar sedang. Skor akhir motivasi belajar pada kelas eksperimen lebih tinggi dari kelas kontrol yaitu secara berturut-turut 81.41 untuk kelas kontrol, 88.72 pada kelas eksperimen 1 dan 87.77 untuk kelas eksperimen 2. Skor akhir kelas kontrol pada kategori motivasi belajar sedang sedangkan kelas eksperimen pada kategori motivasi belajar tinggi.

\section{Analisis Data Sebelum Perlakuan Uji prasyarat analisis}

Uji persyaratan analisis dilakukan dengan uji normalitas data menggunakan Shapiro-Wilk, sedangkan uji homogenitas data dilakukan dengan uji levene statistic menggunakan fasilitas SPSS (Statistical Package for the Social Sciences) versi 17.00. Uji normalitas pretest prestasi belajar dan skor awal motivasi belajar menggunakan uji Shapiro Wilk dengan taraf signifikansi 0,05 . Untuk uji homogenitas menggunakan uji Levene dengan taraf signifikansi 0,05.

Hasil uji Shapiro Wilk pretest berupa nilai signifikansi sebesar 0.062 untuk kelas eksperimen 1, eksperimen 2 adalah 0.75 dan 0.862 pada kelas kontrol. Nilai signifikansi atau $p$ lebih besar dari 0.05 maka ketiga sampel berasal dari populasi yang berdistribusi normal. Uji normalitas skor awal motivasi belajar sebesar 0,445 untuk eksperimen 1, eksperimen 2 0,592, dan 0,749 untuk kelas kontrol. Nilai signifikansi atau $p$ lebih besar dari 0.05 maka ketiga sampel berasal dari populasi yang berdistribusi normal.

Hasil uji Levene untuk data pretest yaitu 0.732, 0.903, dan 0.556 secara keseluruhan nilai signifikansinya $>0,05$. Untuk uji Levene skor akhir motivasi belajar yaitu 0.367, 0.543, dan 0.499556 secara keseluruhan nilai signifikansinya $>0,05$. Dengan demikian ketiga sampel sampel berasal dari populasi-populasi yang mempunyai varians yang sama atau homogen.

Uji Kesamaan Rata-rata Pretest dan Skor Awal Motivasi Belajar

Analisis data awal dilanjutkan dengan menggunakan uji statistik parametrik dengan menggunakan anova dengan taraf signifikansi 0.05 dikarenakan uji prasyarat analisis terpenuhi. Hasil uji one way anova untuk pretest adala h 0.990 dan untuk skor 
awal motivasi belajar 0.543 yang artinya tidak ada perbedaan yang signifikan. Berdasarkan hasil analisis data tes awal prestasi belajar dan data awal motivasi belajar kelas ekperimen dan kelas kontrol, diperoleh kesimpulan bahwa tidak terdapat perbedaan rata-rata skor tes awal dan skor awal antara kelas eksperimen dan kelas kontrol. Artinya kemampuan dan rata-rata motivasi belajar dari kelas kontrol dan kelas eksperimen adalah sama.

\section{Analisis Data Sesudah Perlakuan Uji prasyarat analisis}

Uji normalitas data tes akhir dan data skor akhir motivasi belajar untuk setiap kelas dengan menggunakan uji Shapiro Wilk dengan taraf signifikansi 0,05. Untuk uji homogenitas menggunakan uji Levene dengan taraf signifikansi 0,05 menggunakan fasilitas SPSS (Statistical Package for the Social Sciences) versi 17.00.

Hasil uji normalitas posttest didapatkan nilai signifikansi 0.090 pada kelas ekperimen 1 dan 0.117 pada kelas ekperimen 2 serta 0.742 pada kelas kontrol. Dengan demikian dapat ditarik kesimpulan bahwa ketiga sampel berasal dari populasi yang berdistribusi normal karena nilai signifikansi lebih besar dari 0.05.

Uji normalitas skor akhir motivasi belajar didapatkan nilai signifikansi 0.482 pada kelas eksperimen 1, pada kelas eksperimen 2 sebesar 0.487, dan pada kelas kontrol 0.717. Nilai signifikansi lebih besar dari 0.05 sehingga dapat ditarik kesimpulan bahwa ketiga sampel berasal dari populasi yang berdistribusi normal.

Hasil uji homogenitas menggunakan uji Levene dengan taraf signifikansi 0,05 untuk posttest yaitu $0.154,0.363$ dan 0.394. Dari hasil uji Levene didapat nilai signifikansinya secara keseluruhan lebih besar dari 0.05, maka dapat disimpulkan ketiga sampel berasal dari populasi yang mempunyai varians yang sama atau homogen.

Hasil uji homogenitas skor akhir motivasi belajar homogenitas menggunakan uji Levene dengan taraf signifikansi 0,05 yaitu nilai siginifikansi sebesar $0.933,0.543$ dan 0.499. Dari hasil uji Levene didapat nilai signifikansinya secara keseluruhan lebih besar dari 0.05, maka dapat disimpulkan ketiga sampel berasal dari populasi yang mempunyai varians yang sama atau homogen.

\section{Uji Hipotesis}

Uji hipotesis dengan menggunakan uji statistik parametrik, yaitu one way anova dan one sample t test dengan taraf signifikansi 0.05 dengan bantuan SPSS 17.00.

\section{Uji Hipotesis 1}

Uji hipotesis pertama menggunakan one way anova. Hasil pengujian dengan anova diperoleh nilai Sig. adalah 0.008 seperti terlihat pada tabel 4 .

Tabel 4 menunjukkan bahwa nilai sig. $0.008<0.05$ maka Ho ditolak. Sehingga dapat disimpulkan bahwa ada perbedaan signifikan pada prestasi belajar antara pembelajaran dengan media visual dengan pembelajaran konvesional tanpa media visual pada pembelajaran tematik tema kegiatan sehari-hari siswa kelas III SD segugus 01 Kecamatan Imogiri. Selanjutnya melalui uji PostHoc LSD diketahui perbedaan antara kelas kontrol dengan kelas Eksperimen 1 adalah -10.86861 dengan nilai signifikansi 0.05 dan kelas kontrol dengan kelas Eksperimen 2 adalah -10.53932 dengan nilai signifikansi 0.05 sehingga dapat

Tabel 4. Uji Anova Posttest

\begin{tabular}{cccccc}
\hline & Sum of Squares & Df & Mean Square & F & Sig. \\
\hline Between Groups & 1055.436 & 2 & 527.718 & 5.322 & .008 \\
Within Groups & 4858.308 & 49 & 99.149 & & \\
\hline
\end{tabular}

Efektivitas Penggunaan Media Visual terhadap Motivasi Belajar dan Prestasi Belajar Siswa ... 
dikatakan bahwa antar kelas kontrol dengan kelas Eksperimen 1 dan Eksperimen 2 memiliki perbedaan yang signifikan.

\section{Uji Hipotesis 2}

Pengujian terhadap efektif tidaknya penggunaan media visual terhadap prestasi belajar diuji dengan uji one sample t test uji pihak kanan. Dengan patokan KKM tema kegiatan sehari-hari yaitu hasil uji one sample $t$ test untuk aspek kognitif prestasi belajar secara berturut-turut yaitu 0.324 untuk kelas kontrol, 0.002 untuk kelas eksperimen 1 dan 0.003 untuk kelas eksperimen 2. Dapat ditarik kesimpulan bahwa nilai pada kelas kontrol tidak lebih tinggi dari KKM dan nilai pada kedua kelas eks perimen lebih tinggi dari nilai KKM dengan prosentase ketuntasan $33.33 \%$ di kelas kontrol, untuk kelas eksperimen 1 yaitu 83.33 $\%$ dan kelas eksperimen 2 adalah $81.81 \%$. Sehingga bisa disimpulkan bahwa penggunaan media visual pada pembelajaran tematik tema kegiatan sehari-hari lebih efektif terhadap aspek kognitif prestasi belajar siswa kelas III SD se-gugus $01 \mathrm{Ke}-$ camatan Imogiri.

\section{Uji Hipotesis 3}

Uji hipotesis kedua menggunakan one way anova. Hasil pengujian dengan anova diperoleh nilai Sig. pada skor akhir motivasi belajar yaitu $0.099>0.05$. seperti terlihat pada tabel 5 .

Tabel 5 menunjukkan nilai sig 0.099 yaitu lebih besar dari 0.05. Dari hasil uji PostHoc LSD perbedaan hanya pada kelas kontrol dengan kelas eksperimen 1 dengan perbedaan rata-rata -7.306 dengan nilai signifikan 0.04 sehingga dapat dikatakan bahwa skor motivasi belajar antara kelas kontrol berbeda secara signifikan dengan kelas eksperimen 1 namun tidak berbeda secara signifikan antara kelas kontrol dan kelas eksperimen 2. Dapat disimpulkan bahwa tidak ada perbedaan yang signifikan pada motivasi belajar antara pembelajaran dengan media visual dengan pembelajaran konvesional tanpa media visual pada pembelajaran tematik tema kegiatan sehari-hari siswa kelas III SD se-gugus 01 Kecamatan Imogiri.

\section{Uji Hipotesis 4}

Pengujian terhadap efektif tidaknya penggunaan media visual terhadap motivasi belajar diuji dengan uji one sample t test uji pihak kanan. Dengan patokan kategori motivasi belajar yang sudah ditetapkanyaitu 86 berdasarkan kategorisasi skor motivasi belajar menurut Azwar (2014:148) sebagai berikut.

$$
\begin{aligned}
& \mathrm{X}>\mathrm{Mi}+1,5 \mathrm{SDi}=\text { sangat tinggi } \\
& \mathrm{Mi}+0,5 \mathrm{SDi}<\mathrm{X} \leq \mathrm{Mi}+1,5 \mathrm{SDi}=\text { tinggi } \\
& \mathrm{Mi}-0,5 \mathrm{SDi}<\mathrm{X} \leq \mathrm{Mi}+0,5 \mathrm{SDi}=\text { sedang } \\
& \mathrm{Mi}-1,5 \mathrm{SDi}<\mathrm{X} \leq \mathrm{Mi}-0,5 \mathrm{SDi}=\text { rendah } \\
& \mathrm{X} \leq \mathrm{Mi}-1,5 \mathrm{SDi}=\text { sangat rendah }
\end{aligned}
$$

Keterangan:

$\mathrm{X}=$ skor

$\mathrm{Mi}=$ Mean Ideal= 1/2 (skor mak + skor min)

SDi $=$ Standar Deviasi Ideal=1/6 (skor mak - skor min)

Hasil uji one sample $t$ test motivasi belajar secara berturut-turut adalah 0.176 untuk kelas kontrol, 0.242 untuk kelas eksperimen 1 dan 0.340 untuk kelas eksperimen 2. Untuk ketiga kelas dikarenakan nilai $p>\alpha(0.05)$, yang artinya nilai pada ketiga kelas tidak kurang dari standar

Tabel 5. Uji Anova Skor Akhir Motivasi Belajar

\begin{tabular}{lrrrcr}
\hline & Sum of Squares & df & Mean Square & F & Sig. \\
\hline Between Groups & 433.666 & 2 & 216.833 & 2.421 & .099 \\
Within Groups & 4388.391 & 49 & 89.559 & & \\
Total & 4822.058 & 51 & & & \\
\hline
\end{tabular}

JURNAL PENELITIAN ILMU PENDIDIKAN, Volume 8, Nomor 2, September 2015 
yang ditetapkan yaitu 86. Dari analisis statistik deskriptif didapatkan skor motivasi belajar yang memenuhi kriteria tinggi pada masing-masing kelas secara berturutturut yaitu dari $33.33 \%$ pada kelas kontrol, pada kelas eksperimen $155.55 \%$, sedangkan pada kelas eksperimen $254.54 \%$ Sehingga bisa dikatakan bahwa penggunaan media visual pada pembelajaran tematik tema kegiatan sehari-hari lebih efektif dibandingkan dengan penggunaan media konvensional terhadap motivasi belajar siswa kelas III SD se-gugus 01 Kecamatan Imogiri.

\section{Pembahasan}

Hasil dari analisis data sebagaimana yang telah dipaparkan sebelumnya, menunjukkan bahwa ada perbedaan yang signifikan dalam hal aspek kognitif prestasi belajar pada siswa yang belajar dengan media visual dengan siswa yang belajar tanpa media visual. Selain itu, penggunaan media visual terbukti lebih efektif terhadap aspek kognitif prestasi belajar dibandingkan tanpa menggunakan media visual pada pembelajaran tematik dengan tema kegiatan sehari-hari.

Ada faktor penyebab efektifnya penggunaan media visual terhadap prestasi belajar. Faktor tersebut diantaranya bahwa dengan media visual dapat menstimulus anak dalam belajar dan memahami materi yang disampaikan. Hal tersebut sesuai dengan Chun \& Plass (Dolati, 2011:9) yang menyimpulkan bahwa prinsip umum dan alasan untuk belajar pada manusia adalah memori visual. Sehingga bisa dikatakan bahwa seseorang akan mulai belajar dengan mengingat pesan visual yang ia dapatkan. Dengan kata lain seseorang akan dengan mudah mengingat dan memahami apa yang ia pelajari karena adanya bantuan dari memori visual yang mempermudah seseorang untuk mengingat sesuatu. Demikian juga pada seorang siswa. Siswa yang belajar dengan bantuan media visual akan lebih mudah mengingat materi yang dipelajari karena otomatis materi yang dirangkum dalam media visual akan tersimpan dalam memorinya.

Berdasarkan catatan pengamatan selama pembelajaran berlangsung, siswa pada kelas eksperimen pada tiap pertemuan lebih cepat mengingat materi yang telah disampaikan guru, hampir sebagian besar siswa dapat menjawab pertanyaan dari guru saat diberikan pertanyaan lisan oleh guru pada saat guru melakukan refleksi terhadap apa yang dipelajari pada pertemuan tersebut. Hal ini dikarenakan siswa yang belajar dengan media visual akan lebih mudah mengingat materi yang diberikan karena proses pemanggilan informasi lebih cepat dilakukan. Seperti yang telah diungkapkan Cowen (de Jager, 2012:2) bahwa media visual membuat konsep lebih mudah diakses oleh siswa dan meningkatkan pemanggilan kembali informasi. Maknanya bahwa media visual dapat mempermudah siswa untuk memahami konsep dari materi yang sedang diajarkan serta mengingat kembali materi yang disampaikan guru.

Selain itu, media visual juga dapat menumbuhkan rasa senang di dalam diri siswa untuk belajar. Karena selain bermain dengan media visual seperti ular tangga, puzzle dan kartu cari pasangan mereka juga belajar tentang materi-materi yang disampaikan guru. Hal tersebut juga diperkuat Faizah (Saputro Soeharto, 2015:64) yang menyatakan bahwa "siswa pada sekolah dasar memiliki ketertarikan yang tinggi terhadap gambar visual dan juga terhadap cerita". Dengan media visual yang ada siswa lebih antusias dalam belajar sehingga lebih mudah mengingat materi-materi yang dipelajari. Hal tersebut juga terjadi pada kelas eksperimen. Siswa pada kelas eksperimen menjadi lebih asyik belajar dan lebih bersemangat. Sedangkan siswa di kelas kontrol masih banyak yang terlihat mengantuk dan asyik menggambar ataupun berbicara dengan teman saat guru menjelaskan. Selain itu saat guru

Efektivitas Penggunaan Media Visual terhadap Motivasi Belajar dan Prestasi Belajar Siswa ... 
merangkum materi di papan tulis, masih ada beberapa siswa yang harus disuruh guru agar mau menuliskan di buku tulisnya masing-masing.

Hal di atas sesuai dengan Baylor \& Richie (Abdo \& Semela, 2010:78) bahwa penggunaan media pembelajaran oleh guru dapat mempertahankan perhatian siswa, meningkatkan kebermaknaan konsep-konsep abstrak, mendorong pemrosesan yang mendalam, dan meningkatkan kinerja kelas melalui peningkatan akuisisi konten. Artinya bahwa media pembelajaran yang digunakan guru dapat menarik perhatian siswa, memperjelas materi serta membantu siswa dalam memahami materi yang abstrak. Hal di atas benar adanya karena siswa pada kelas eksperimen yang menggunakan media visual terlihat lebih aktif, bersemangat dan lebih fokus pada pembelajaran.

Pada intinya, media memang memegang peranan penting dalam proses pembelajaran terutama pada prestasi belajar siswa. Hasil temuan dan analisis di atas membuktikan bahwa media visual terbukti efektif terhadap aspek kognitif prestasi belajar siswa dalam tema kegiatan sehari-hari. Hal tersebut juga mendukung temuan-temuan lain yang telah dituliskan oleh beberapa penelitian sebelumnya yang menyatakan bahwa penggunaan media visual ataupun media pembelajaran di kelas berhubungan erat dengan prestasi belajar siswa. Seperti yang dituliskan Kumari \& Rani (2012:41) bahwa ada efek yang besar dari media pembelajaran pada prestasi akademik siswa. Intinya bahwa media sangat berperan dalam perhatian dan ingatan siswa, penyampaian pesan pembelajaran serta prestasi belajar siswa.

Selanjutnya untuk uji anova menunjukkan bahwa tidak ada perbedaan secara signifikan terhadap motivasi belajar. Perbedaan yang signifikan hanya pada kelas kontrol dan kelas eksperimen 1 saja. Namun berdasarkan uji one sample t test dan analisis statistik deskriptif media visual lebih efektif bila digunakan bila dibandingkan media konvensional yaitu kapur tulis dan kapur berwarna. Untuk efektivitas penggunaan media visual yang lebih efektif terhadap motivasi belajar sejalan dengan Aisami (2015:242) yaitu bahwa media visual selain berdampak pada memori dan kinerja siswa juga berdampak pada positif pada motivasi. Pada penelitian ini, efektivitas media visual berdampak positif dengan prosentase motivasi belajar siswa yang tinggi pada kedua kelas eksperimen lebih dari 50\%. Berdasarkan statatistik deskriptif skor akhir motivasi belajar siswa di kelas eksperimen tetap lebih tinggi daripada skor akhir motivasi belajar siswa di kelas kontrol. Selain itu dari catatan peneliti (rangkuman catatan pengamatan peneliti selengkapnya di lampiran), siswa yang belajar dengan media visual terlihat lebih bersemangat.

Ada beberapa faktor yang harus diperhatikan agar media visual lebih efektif lagi untuk digunakan dalam meningkatkan motivasi belajar siswa. Faktor tersebut diantaranya adalah dalam hal penyajiannya. Smaldino, Lowther, \& Russel (2012:332) menyatakan bahwa penggunaan media visual di kelas harus memperhatikan beberapa hal diantaranya yaitu menggunakan hanya satu sajian visual dalam satu periode waktu. Arti satu periode waktu dalam sebuah proses pembelajaran adalah tidak hanya sekali atau dua kali saja namun lebih dari itu, hal ini agar lebih fokus dan membekas pada diri siswa. Media visual seperti puzzle, ular tangga dan kartu cari pasanganku hanya diberikan kepada siswa masing-masing dua kali pertemuan saja. Akan lebih efektif jika untuk pembelajaran di kelas eksperimen masing-masing media diberikan lebih dari 2 kali. Hal ini akan memungkinkan siswa untuk mengenal lebih dalam media tersebut. Alasan tersebut sesuai dengan kondisi saat pembelajaran berlangsung pada kelas eksperimen yaitu ada beberapa siswa yang mengatakan belum puas bermain dengan 
media yang telah digunakan karena hanya dipraktekkan dua kali pertemuan.

Faktor lain yang juga dituliskan oleh Smaldino, Lowther, \& Russel (2012:332) adalah bahwa penggunaan media visual harus bisa dilihat secara serempak oleh setiap siswa. Tujuannya tentu saja agar setiap siswa mempunyai kesempatan yang sama untuk belajar dengan media visual yang digunakan. Dalam penelitian ini, penggunaan media visual secara berkelas antara 4-6 siswa sehingga tidak bisa dipungkiri ada beberapa siswa yang kurang maksimal dalam menggunakan media visual yang diberikan. Hal ini sesuai dengan prinsip umum agar media visual lebih efektif seperti yang dituliskan Arsyad (2014:90) yaitu mengulangi sajian visual dan melibatkan semua siswa. Artinya adalah dalam pembelajaran dengan media visual harus memperhatikan penggunaannya yaitu memberi kesempatan yang sama kepada semua siswa untuk menggunakannya.

Selain hal tersebut di atas, faktor lain yang harus diperhatikan agar penggunaan media visual lebih efektif lagi untuk meningkatkan motivasi belajar siswa disebutkan oleh Sudjana \& Rivai (2011:26) yaitu diantaranya pertimbangan dalam segi artistiknya seperti kesederhanaan, keterpaduan, komposisi, penekanan, keseimbangan, ruang, tekstur, serta warna. Tentu saja hal-hal tersebut penting untuk diperhatikan dikarenakan dengan mempertimbangkan beberapa hal seperti kesederhanaan, keterpaduan, komposisi, penekanan, keseimbangan, ruang, tekstur, serta warna pada media yang akan digunakan akan berdampak pada efektif tidaknya media itu sendiri. Selain itu dengan mempertimbangkan beberapa hal tersebut, media yang dihasilkan tentu saja akan lebih menarik dan mempertinggi motivasi belajar. Media visual dalam penelitian ini belum sepenuhnya mempertimbangkan hal-hal tersebut. Diantaranya adalah tekstur dan warna. Tekstur dalam media visual dalam penelitian ini belum ada. Selanjutnya adalah warna. Warna dalam media visual yang digunakan masih kurang bervariasi dan atraktif sehingga bagi sebagian siswa kurang menarik.

Telah dipaparkan analisis data mengenai hasil dari penelitian yang telah dilaksanakan. Hasil analisis atau penskoran menunjukkan bahwa kelas yang mendapat perlakuan dengan media visual berbeda dengan kelas yang tidak menggunakan media visual terutama dalam hal aspek kognitif prestasi belajar. Perbedaan prestasi belajar siswa dapat dilihat dari hasil perhitungan skor rerata pretest dan posttest. Sedangkan perbedaan motivasi belajar dilihat dari hasil perhitungan skor awal dan skor akhir motivasi belajar.

Dengan demikian dari hasil temuan penelitian dan analisis data di atas dapat disimpulkan bahwa terdapat perbedaan yang signifikan pada aspek kognitif prestasi belajar pada tema kegiatan sehari-hari antara siswa yang belajar menggunakan media visual dengan siswa yang belajar tanpa media visual serta penggunaan media visual seperti puzzle, ular tangga dan kartu cari pasangan pada pembelajaran tematik tema kegiatan sehari-hari lebih efektif dibandingkan tanpa menggunakan media visual terhadap aspek kognitif prestasi belajar. Selanjutnya tidak terdapat perbedaan yang signifikan dari segi motivasi belajar serta namun penggunaan media visual lebih efektif daripada penggunaan media konvensional terhadap motivasi belajar. Pemilihan media yang tepat, akan menumbuhkan rasa senang untuk belajar materi yang disampaikan oleh guru sehingga prestasi belajar akan meningkat. Oleh karena itu, seorang guru harus mampu memilih dan menggunakan media pembelajaran yang efektif untuk meningkatkan hasil pembelajaran dan motivasi belajar siswa. Media visual merupakan salah satu media yang terbukti efektif digunakan dalam pembelajaran tematik tema kegiatan sehari-hari sehingga prestasi belajar dan motivasi belajar siswa meningkat.

Efektivitas Penggunaan Media Visual terhadap Motivasi Belajar dan Prestasi Belajar Siswa ... 


\section{PENUTUP \\ Simpulan}

Berdasarkan hasil penelitian dan pembahasan maka dapat disimpulkan sebagai berikut 1) Ada perbedaan yang signifikan pada prestasi belajar antara siswa yang diajar dengan menggunakan media visual yaitu puzzle, ular tangga dan kartu cari pasangan dengan siswa yang menggunakan media konvensional konvensional papan tulis dan kapur berwarna pada pembelaran tematik tema kegiatan seharihari pada siswa kelas III SD Gugus 01 Kecamatan Imogiri; 2) Penggunaan media visual seperti puzzle, ular tangga dan kartu cari pasangan lebih efektif dibandingkan dengan penggunaan media konvensional papan tulis dan kapur berwarna terhadap aspek kognitif prestasi belajar siswa pada pembelajaran tematik tema kegiatan sehari-hari pada siswa kelas III SD Gugus 01 Kecamatan Imogiri; 3) Tidak ada perbedaan yang signifikan pada motivasi belajar antara siswa yang diajar dengan menggunakan media visual yaitu puzzle, ular tangga dan kartu cari pasangan dengan siswa yang menggunakan media konvensional konvensional papan tulis dan kapur berwarna pada pembelaran tematik tema kegiatan sehari-hari pada siswa kelas III SD Gugus 01 Kecamatan Imogiri; 4) Penggunaan media visual seperti puzzle, ular tangga dan kartu cari pasangan lebih efektif dibandingkan dengan penggunaan media konvensional konvensional papan tulis dan kapur berwarna terhadap aspek motivasi belajar siswa pada pembelajaran tematik tema kegiatan sehari-hari pada siswa kelas III SD Gugus 01 Kecamatan Imogiri.

\section{Saran}

Saran dari hasil penelitian ini adalah 1) Sekolah hendaknya menyediakan fasilitas pembelajaran khususnya pembelajaran tematik agar tujuan pembelajaran dapat tercapai; 2) Guru sebaiknya menggunakan macam-macam media pembelajaran tematik sehingga pembelajaran lebih menarik dan menyenangkan; 3) Sebaiknya guru bersedia menggunakan media visual seperti puzzle, ular tangga dan kartu cari pasanganku sebagai salah satu media pembelajaran tematik; 4) Penggunaan media visual sebaiknya mempertimbangkan beberapa unsur artistic seperti kesederhanaan, komposisi, dan pewarnaan agar lebih efektif lagi untuk meningkatkan motivasi belajar; 5) Penggunaan media visual sebaiknya mempertimbangkan waktu penyajiannya yaitu berulang-ulang dan jika dilakukan secara berkelompok harus dipastikan setiap kelompok anggotanya tidak terlalu banyak yaitu antara 2-3 siswa.

\section{DAFTAR PUSTAKA}

Abdo, M., \& Semela, T. (2010). Teachers of poor communities: The tale of instructional media use in primary schools of Gedeo Zone, Southern Ethiopia. Australian Journal of Teacher Education, 35(7), 77-92.

Aisami, R. S. (2015). Learning styles and visual literacy for learning and performance. Procedia - Social and Behavioral Sciences, 176, $538-545$.

Arsyad, A. (2014). Media pembelajaran. Jakarta: Raja Grafindo Persada.

Azwar, S. (2014). Penyusunan skala psikologi. Yogyakarta: Pustaka Pelajar.

Benson, A. \& Odera, F. (2013). Selection and use of media in teaching kiswahili language in secondary schools in Kenya.. International Journal of Information and Communication Technology Research, 3(1). 12-18.

de Jager, T. (2012). Using visual media to enhance science teaching and learning in historically disadvantaged secondary schools. International Proceedings of Economics Development and Research, $47,1-6$.

Dolati, R. (2011). Harnessing the use of visual learning aids in the english lan- 
guage classroom. Arab World English Journal, 2, 3-17.

Kumari, S. \& Rani. G. (2012). Efficacy of different instructional media on academic achievement of class XII students. Internasional Idexed \& Reffered Research Journal, 1, 41-42.

Majid, A. (2014). Pembelajaran Tematik Terpadu. Bandung: Remaja Rosdakarya.

Ngure, G., et.al. (2014). Instructional media for quality training in pre-primary school teacher training colleges in Nairobi County, Kenya. Researchjournali's Journal of Education, 2 (7), 1-22.

Saputro, H. \& Soeharto, S. (2015). Pengembangan media komik berbasis pendidikan karakter pada pembelajaran tematik-integratif kelas IV SD. Jurnal Prima Edukasia. Diambil pada tanggal 11 November 2015, dari: http://jour- nal.uny.ac.id/ index.php/jpe/article/ view/4065.

Shaughnessy, J. J, Zechmeister, E. B., \& Zechmeister, J. S. (2012). Metode Penelitian dalam Psikologi. Edisi sembilan. (Terjemahan Ellys Tjo). New York: McGraw-Hill.

Smaldino, S. E, Lowther, D. L, \& Russel, J. D. (2012). Instructional technology $\mathcal{E}$ media for learning: Teknologi pembelajaran dan media untuk belajar. Edisi kesembilan. (Terjemahan Arif Rahman). New York: Pearson Education, Inc (buku asli diterbitkan 2011).

Sudjana, N. \& Rivai, A. (2011). Media pengajaran. Bandung: Sinar Baru Algesindo.

Sukini. (2012). Pembelajaran tematik di sekolah dasar kelas rendah dan pelaksanaannya. Magistra, 82, 59-69. 